\title{
Processed and ultra-processed food consumption are related to metabolic markers in hemodialysis subjects
}

\section{Consumo de alimentos processados e ultraprocessados}

está relacionado a marcadores metabólicos

em indivíduos em hemodiálise

\author{
Aline Lage WENDLING ${ }^{1}$ (D) 0000-0002-2432-921X \\ Karla Pereira BALBINO ${ }^{1}$ (D) 0000-0002-9273-5180 \\ Priscila Vaz de Melo RIBEIRO ${ }^{1}$ (D) 0000-0002-6996-1796 \\ Andreza de Paula Santos EPIFÂNIO' ${ }^{1}$ (D) 0000-0003-4054-5315 \\ Luciane Domingos MAROTA ${ }^{1}$ (D) 0000-0002-3318-450X \\ Helen Hermana Miranda HERMSDORFF ${ }^{1}$ (D) 0000-0002-4441-6572
}

\section{A B S T R A C T}

\section{Objective}

To investigate the consumption of processed and ultra-processed foods and evaluate its relationship with the nutritional and metabolic status of hemodialysis patients in a single center in Brazil.

\section{Methods}

This cross-sectional study enrolled 73 individuals in hemodialysis (50 men and 23 women, 21-87 years-old). Clinical and lifestyle variables were assessed by a semi-structured questionnaire and dietary data by food frequency questionnaire. Anthropometric and metabolic data are collected from medical records.

\section{Results}

Processed and ultra-processed foods represented $11.0 \%$ of daily caloric intake, $53.0 \%$ of trans fatty acid, and $12.5 \%$ of salt consumed in the study sample. Individuals who had high intake of this food group $(\geq 128.4 \mathrm{~g} / \mathrm{day}$, median intake) had higher serum phosphorus and pre-dialysis urea values ( $p=0.038 ; p=0.013$, respectively).

\footnotetext{
1 Universidade Federal de Viçosa, Programa de Pós-Graduação em Ciência da Nutrição, Departamento de Nutrição e Saúde. Av. P. H. Rolfs, s/n., Campus Universitário, 36570-900, Viçosa, Minas Gerais, Brasil. Correspondence to: HHM Hermsdorff. E-mail: <helenhermana@ufv.br>.

How to cite this article

Wendling AL, Balbino KB, Ribeiro PVM, Epifânio APS, Marota LD, Hermsdorff HHM. Processed and ultra-processed food consumption are related to metabolic markers in hemodialysis subjects. Rev Nutr. 2020;33e190138. http://dx.doi. org/10.1590/1678-9865202033e190138
} 
Also, individual with higher consumption of processed meat, sausages and ready prepared food had higher pre-dialysis serum urea $(p=0.021)$, while serum potassium was higher among the subjects who consumed more sauces and salt-based seasonings $(p=0.002)$.

\section{Conclusion}

Higher consumption of processed and ultra-processed foods was associated with important biomarkers of metabolic control for hemodialysis subjects, probably due to non-health dietary composition. Nutritional guidelines and intervention strategies must be promoted to reduce consumption of these food-group in this specific population.

Keywords: Blood urea nitrogen. End stage kidney disease. Food intake. Food-processing industry. Renal dialysis. Trans fatty acids.

\section{RE S U M O}

\section{Objetivo}

Investigar o consumo de alimentos processados e ultraprocessados e avaliar sua relação com o estado nutricional e metabólico de pacientes em hemodiálise em um único centro brasileiro.

\section{Métodos}

Este é um estudo transversal com 73 individuos em hemodiálise (50 homens e 23 mulheres, 21-87 anos de idade). As variáveis clínicas e de estilo de vida foram avaliados por um questionário semi-estruturado, bem como dados dietéticos por questionário de frequência alimentar. Dados antropométricos e metabólicos foram coletados de registros médicos.

\section{Resultados}

Os alimentos processados e ultraprocessados representaram 11,0\% das calorias diárias, 53,0\% dos ácidos graxos trans e $12,5 \%$ de sódio consumido na amostra estudada. Os indivíduos que tiveram alta ingestão deste grupo alimentar ( $\geq 128,4 \mathrm{~g} /$ dia, ingestão mediana) apresentaram maiores valores de fósforo sérico e uréia prédiálise ( $p=0,038 ; p=0,013$, respectivamente). Também, indivíduos com maior consumo de carne processada, embutidos e refeições prontas apresentaram maior ureia sérica pré-diálise $(p=0,021)$, enquanto o potássio sérico foi maior entre os indivíduos que consumiram mais molhos e temperos á base de sal $(p=0,002)$.

\section{Conclusão}

O maior consumo de alimentos processados e ultraprocessados foi associado a importantes biomarcadores de controle metabólico para indivíduos em hemodiálise, provavelmente devido à composição dietética não saudável. Orientações nutricionais e estratégias de intervenção devem ser promovidas para reduzir o consumo desses alimentos nessa população específica.

Palavras-chave: Nitrogênio ureico sérico. Falência renal crônica. Consumo alimentar. Indústria de processamento de alimentos. Diálise renal. Ácidos graxos trans.

\section{INTRODUCTION}

The number of individuals with Chronic Kidney Disease (CKD) has gradually increased, and Hemodialysis (HD) is the most widely used kidney replacement therapy for those individuals requiring continuing care [1]. The main complications affecting individuals with CKD Stage-5 is the protein-energy malnutrition and mineral disorders, such as hyperphosphatemia and hypocalcemia, leading to complications as secondary hyperparathyroidism and bone metabolism disorders [2].

Nutritional monitoring is important for the prevention, control or treatment of malnutrition, changes in mineral metabolism, uremic toxicity and other complications that can affect these individuals [1]. However, the nutritional transition has led to a reduction of the regular consumption of food rich in fiber, vitamins and minerals in contrast to the increased consumption of processed 
and ultra-processed food with high levels of saturated and trans fat, sugar and sodium [3]. These foods are also added to this inorganic phosphorus, which is more easily absorbed, increasing serum concentrations of this mineral in the bloodstream [4]. In addition, the nutritional composition of these could negatively modulate the lipid metabolism and other complications already prevalent in individuals with CKD Stage-5 [5].

Although processed and ultra-processed foods have been associated with chronic diseases such as obesity and cardiovascular disease [3]; their relationships with metabolic markers in individuals with CKD Stage-5 have not been apparently reported. The aim of this study was to investigate the food consumption according to the type of processing (processed and ultra-processed) and its relation to metabolic markers in hemodialysis subjects.

\section{METHODS}

This cross-sectional study enrolled 73 patients with CKD in HD older than 18 years (21 until 87 years-old) and regularly assisted in the HD unit between October and November 2015. Individuals who did not express interest in participating of the study, with treatment time in HD shorter than a month, with hearing impairment, newly implanted catheters, hemodynamic instability, assessed by the medical sector, were not included. This study was approved by the Ethics Committee in Human Research, according to the Resolution 466/2012 of the National Health Council of the Ministry of Health, Brazil (Protocol number: 701.796/2014, CAAE: 27364314.8.00005153). All participants read and signed a written informed consent, in accordance to principles of the Declaration of Helsinki.

Subjects were characterized according to age, sex, weight-status, HD time, clinical data and life habits. This information was collected from records and interviews during the HD session.

Anthropometric data, clinical and metabolic markers were collected from medical records. In this sense, the dry weight $(\mathrm{kg})$, measured immediately after the HD section, and height $(\mathrm{cm})$ were collected and the Body Mass Index (BMI) was calculated, followed by classification according to the World Health Organization for adults [6] and Lipschitz [7] for elderly.

Serum values of phosphorus, potassium, calcium, pre-dialysis urea, post-dialysis urea, Kt $N$, calcium-phosphorus product, creatinine, hemoglobin, postprandial blood glucose, total cholesterol and triglycerides were also collected. The reference values were those adopted by dialysis unit, considering optimal postprandial glucose $<7.77 \mathrm{mmol} / \mathrm{L}$ [8]; serum phosphorus 1.13 to $1.77 \mathrm{mmol} / \mathrm{L}$ [9]; serum potassium 3.5 to $5.5 \mathrm{mmol} / \mathrm{L}$ [10]; triglycerides $<2.26 \mathrm{mmol} / \mathrm{L}$ [11]; total cholesterol $<5.18 \mathrm{mmol} / \mathrm{L}$ [11]; calcium 2.1 to $2.37 \mathrm{mmol} / \mathrm{L}$ [9]; pre-dialysis urea 53.5 to $71.4 \mathrm{mmol} / \mathrm{L}$ [12]; postdialysis urea $<21.42 \mathrm{mmol} / \mathrm{L}$ [13]; KtN $\geq 1.2$ [13]; calcium-phosphorus product $<55 \mathrm{mg}^{2} / \mathrm{dL}^{2}$ [9]; creatinine 884-1.060.8 $\mathrm{mol} / \mathrm{L}$ [12]; hemoglobin 120g/L for women and 130g/L for men [9].

A food-frequency questionnaire was elaborated with 200 food items, based on a previous validated food-frequency questionnaire for individuals with CKD [14], in which the foods are divided into: fresh food or minimally processed (vegetables, tubers, fruits, fresh meats, eggs and pasteurized milk), processed (canned vegetables in water or brine, fruit in syrup or dehydrated, dried meat and bacon, sauces and tomato extracts) and ultra-processed food (ice creams, cookies, pasta, refreshment and soft drinks, breakfast cereals, pizzas, hamburgers, sausages and other meats), according the classification of the second edition of the Food Guide for Brazilian Population [15]. In addition, food items were categorized according to nutritional composition and classification of the Food Guide for Brazilian Population [15], as follows: preserved and canned (palm, olives, pickles, tuna, sardine, fruits 
in syrup, green corn and peas); refined flours (crackers; sweet and stuffed cookie; cake and pie; general breads; foods rich in simple carbohydrates and that present less amount of fiber and micronutrient compared to the unrefined ones); dairy products and derivatives (cheese, dairy drinks, yogurts, butter, cream cheese and grated parmesan cheese); sausages and processed meats (jerked beef, bacon, hamburger steak, nuggets, steaks, sausages, ham, mortadella and turkey breast); candies (ice cream, popsicle, chocolate, cereal bar, snack type Cheetos and dehydrated sweet); sauces and seasoning salt-based (extracts or concentrates of tomato, mustard sauce, ketchup, mayonnaise, Knorr broth, English and garlic sauce); soft drinks and artificial juices; preparations ready or semi-ready (instant noodles, pizza, dehydrated powdered soups and sticks potato); and other ultra-processed food (vegetable cream and breakfast cereals) [16].

The food-frequency questionnaire was applied in the dialysis unit, by trained researchers, in the days of routine HD sessions. For patients unable to respond, or who resided in special nursing homes, the questions were addressed to those in charge of them. During the application of the foodfrequency questionnaire a photographic album with similar portions was used during the interview so that the interviewee chose the categories of portions of the food groups that corresponded to their usual intake.

Nutrient intake was estimated using an ad hoc Microsoft Excel Sheet (Chicago, Illinois, United States of America, version 2010) specifically developed for this aim. A dietitian updated the nutrient data bank using the latest available information included in the food composition tables for Brazil (Family Budget Survey/Pesquisa de Orçamento Familiares 2008-2009) [17]. Nutrient intake was calculated as frequency $\times$ nutrient composition of each portion size for each consumed food item. Frequencies were measured in four frequency categories (daily, weekly, monthly and yearly), while portion sizes were based on first edition of the Food Guide for Brazilian population [18] for each food item. The nutritional information of foods not found in the nutritional composition table was recorded from their labels.

The results are presented as means (standard deviation) or median (interquartile range), according to distribution of the variables, determined by the Shapiro-wilk test. The qualitative variables were described by relative frequency (\%). The Student t test was applied for parametric variables, while Mann Whitney U-test was used for the non-parametric variables. To evaluate the distribution among the groups the Chi-square test $\left(\chi^{2}\right)$ was applied. All nutrients evaluated in this study were adjusted by the daily caloric intake by residual method before performing the analyses [19]. To assess the associations of processed and ultra-processed food consumption with studied variables, we categorized the participants by median of food-group consumption, being the sample divided into low ( $<128.4 \mathrm{~g} /$ day) and high consumption ( $\geq 128.4 \mathrm{~g} /$ day). The median cutoff criteria have been previously applied [20] and are based on a valid and reliable method to assign two or more groups of risk in nutritional epidemiology studies [21]. Statistical analyses were processed using the Statistical Package for the Social Sciences ${ }^{\circledR}\left(\right.$ IBM $^{\circledR}$, New York, version 20.0). The $p$-value $<0.05$ was considered statistically significant.

\section{RE S U L T S}

Most participants were men (68.5\%) and the mean age was $62.4 \pm 13.5$ years. Regarding the anthropometric evaluation $49.3 \%$ of the subjects were normal-weight, $23.3 \%$ overweight and 27.4\% underweight. When compared by sex, women had longer dialysis time and higher BMI, while high serum phosphorus concentration occurred only among men. Furthermore, there was a difference in post-dialysis urea $(p=0.013)$ and $\mathrm{Kt} N(p=0.001)$ compared between sex (Table 1$)$. 
Table 1. Demographic, clinical, metabolic and nutritional characteristics of hemodialysis individuals, according to sex ( $n=73$ ). Viçosa, (MG), Brazil, 2015.

\begin{tabular}{|c|c|c|c|c|c|c|c|c|}
\hline \multirow{2}{*}{ Variables } & \multicolumn{2}{|c|}{ Men $(n=50)$} & \multicolumn{2}{|c|}{ Women $(n=23)$} & \multicolumn{2}{|c|}{ Men $(n=50)$} & \multicolumn{2}{|c|}{ Women $(n=23)$} \\
\hline & M & $\pm \mathrm{SD}$ & M & $\pm \mathrm{SD}$ & $\mathrm{N}$ & $\%$ & $\mathrm{~N}$ & $\%$ \\
\hline BMI $\left(k g / m^{2}\right)^{a}$ & 23.0 & 3.4 & $24.9^{*}$ & $4.1^{*}$ & - & - & - & - \\
\hline HD time (months) & 66.0 & 50.0 & $88.0^{*}$ & $50.0^{*}$ & - & - & - & - \\
\hline Alcohol consumers $^{c}$ & - & - & - & - & 8.0 & 16.0 & 1.0 & 4.3 \\
\hline Smokers ${ }^{c}$ & - & - & - & - & 9.0 & 18.0 & 2.0 & 8.7 \\
\hline Physical activityc & - & - & - & - & 10.0 & 20.0 & 6.0 & 26.1 \\
\hline $\mathrm{Kt} / \mathrm{N}^{\mathrm{a}}$ & 1.4 & 0.3 & 1.7 & $0.4^{*}$ & - & - & - & - \\
\hline Pre-dialysis urea ${ }^{\mathbf{b}}$ & 115.0 & 30.0 & 111.0 & 31.0 & - & - & - & - \\
\hline Post-dialysis urea ${ }^{\mathbf{b}}$ & 36.6 & 12.2 & 29.4 & $10.9^{*}$ & - & - & - & - \\
\hline Hyperglycemiac & - & - & - & - & 18.0 & 56.3 & 9.0 & 45.0 \\
\hline Diabetes Mellitus ${ }^{c}$ type 1 and 2 & - & - & - & - & 20.0 & 40.0 & 8.0 & 39.1 \\
\hline Hypertriglyceridemiac & - & - & - & - & 14.0 & 28.0 & 8.0 & 34.8 \\
\hline Hypercholesterolemiac $^{c}$ & - & - & - & - & 3.0 & 6.0 & 3.0 & 13.0 \\
\hline Calcium (mg/dL) ${ }^{a}$ & 8.8 & 0.7 & 8.8 & 0.8 & - & - & - & - \\
\hline Phosphorus (mg/dL) $)^{a}$ & 4.2 & 1.3 & 4.7 & $1.1^{*}$ & - & - & - & - \\
\hline Hyperphosphatemiac & - & - & - & - & 12.0 & 24.0 & 0.0 & $0.0^{*}$ \\
\hline Hyperkalemiac & - & - & - & - & 20.0 & 40.0 & 8.0 & 34.8 \\
\hline
\end{tabular}

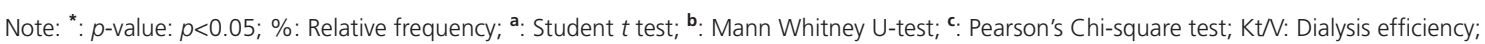
Hypercholesterolemia: Cholesterol $>5.18 \mathrm{mmo} / \mathrm{L}$; Hyperglycemia: Postprandial glucose $>7.77 \mathrm{mmol} / \mathrm{L}$; Hyperkalemia: Serum potassium $>5.5 \mathrm{mmol} / \mathrm{L}$; Hyperphosphatemia: Serum phosphorus >1.77mmol/L; Hypertriglyceridemia: Triglycerides $>2.26 \mathrm{mmol} / \mathrm{L}$.

BMI: Body Mass Index; HD: Hemodialysis; M: Mean; SD: Standard Deviation.

With respect to dietary consumption, the median caloric intake of individuals in HD was $2,526 \mathrm{kcal}$ per day $(937-6,385 \mathrm{kcal} / \mathrm{d})$, being $11.0 \%$ of daily caloric intake from processed and ultra-processed foods. The most consumed foods were the type "refined flours".

Figure 1 shows the contributions of processed and ultra-processed food nutrients relative to the total intake of some nutrients. Trans fatty acids from processed and ultra-processed food were the main contributors in the total daily intake, representing $53.0 \%$ of total consumption. Moreover, individuals with higher consumption of processed and ultraprocessed showed higher energy intake of macro and micronutrients daily, except for carbohydrates and polyunsaturated fat, as shown in Table 2.

Moreover individuals who had higher food consumption of processed and ultraprocessed ( $\geq 128.4 \mathrm{~g} /$ day; 3.3-837), had higher pre-dialysis urea and serum phosphorus values, when compared to those of lower consumption (Table 3). Interestingly, pre-dialysis serum urea was also higher $(p=0.021)$ among individuals with higher consumption of processed meats, sausages and ready preparations (Figure 2 a). The same was observed in consumption of sauces and seasoning salt-based in relation to serum potassium $(p=0.002)$, as shown in Figure 2 b. 


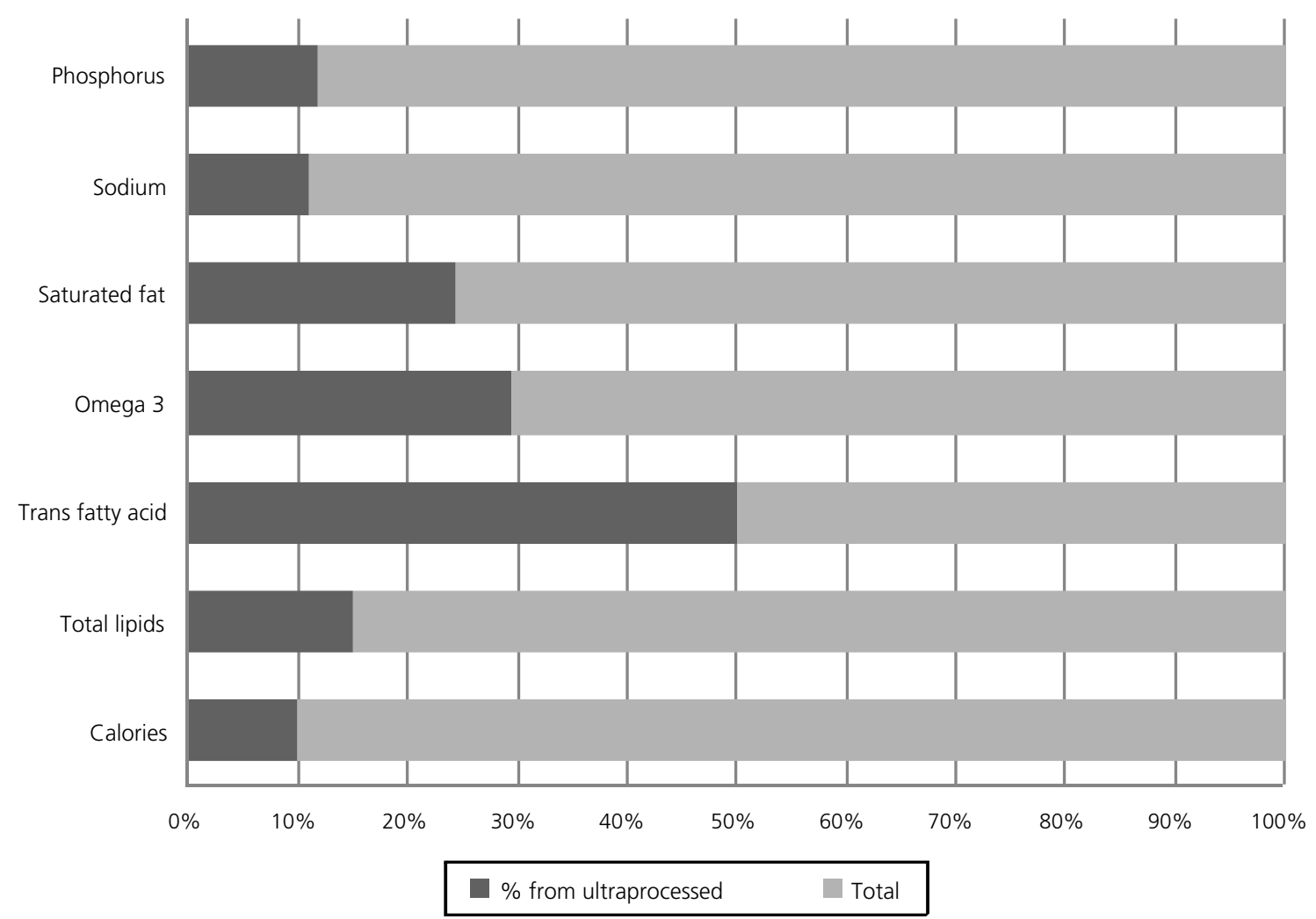

Figure 1. Contribution (\% daily intake) of specific nutrients from processed and ultra-processed foods among hemodialysis individuals $(n=73)$.

Table 2. Daily consumption of calories, macro and micronutrients of individuals according to the consumption of processed and ultra-processed foods. Viçosa, (MG), Brazil, 2015.

\begin{tabular}{|c|c|c|c|c|}
\hline \multirow{3}{*}{ Daily intake } & \multicolumn{2}{|c|}{ Low consumption } & \multicolumn{2}{|c|}{ High consumption } \\
\hline & \multicolumn{2}{|c|}{$<128.4$ (g/day) $(n=36)$} & \multicolumn{2}{|c|}{$\geq 128.4$ (g/day) $(n=37)$} \\
\hline & $M_{d}$ & $\left(P_{25}-P_{75}\right)$ & $M_{d}$ & $\left(P_{25}-P_{75}\right)$ \\
\hline Calories (day) & 1921.0 & $937.0-3798.0$ & 2989.0 & $1251.0-6385.0^{*}$ \\
\hline Protein (g/kg dry weight) & 1.0 & $0.4-2.9$ & 1.4 & $0.5-3.0^{*}$ \\
\hline Lipids (\%Cl) & 31.0 & $5.8-41.5$ & 32.0 & $22.3-36.0^{*}$ \\
\hline Carbohydrates (\%Cl) & 52.0 & $27.0-92.0$ & 48.0 & $45.0-58.0^{*}$ \\
\hline Cholesterol (mg/day) & 198.0 & $14.0-683.0$ & 301.0 & $55.0-760.0^{*}$ \\
\hline Saturated fat (\%Cl) & 8.0 & $5.0-15.0$ & 9.6 & $6.0-10.4^{*}$ \\
\hline Monounsaturated fat (\%Cl) & 9.8 & $5.7-15.0$ & 10.5 & $7.0-11.0^{*}$ \\
\hline Polyunsaturated fat (\%Cl) & 12.0 & $3.8-16.0$ & 11.0 & $4.3-10.4^{*}$ \\
\hline a-Linolenic acid (g/day) & 4.8 & $0.8-16.0$ & 8.0 & $3.0-18.0^{*}$ \\
\hline Linoleic acid (g/day) & 20.0 & $0.0-60.0$ & 27.0 & $4.0-61.0^{*}$ \\
\hline Trans fatty acid (g/day) & 2.5 & $0.4-16.0$ & 4.3 & $1.4-16.0^{*}$ \\
\hline Phosphorus (mg/day) & 778.0 & $323.0-2809.0$ & 1265.0 & $528.0-2783.0^{*}$ \\
\hline Sodium (mg/day) & 3135.0 & $1251.0-7327.0$ & 4747.0 & $1685.0-9655.0^{*}$ \\
\hline
\end{tabular}

Note: *: $p<0.05$ according to Mann Whitney U-test; Cl: Caloric Intake; HD: Hemodialysis; $\mathrm{M}_{\mathrm{d}}$ : Median. 
Table 3. Demographic, clinical, nutritional and metabolic characteristics of Hemodialysis individuals, according to the consumption of processed and ultra-processed foods. Viçosa, (MG), Brazil, 2015.

\begin{tabular}{|c|c|c|c|c|}
\hline \multirow{2}{*}{ Variables } & \multicolumn{2}{|c|}{ Low consumption $<128.4$ (g/day) $(n=36)$} & \multicolumn{2}{|c|}{ High consumption $\geq 128.4$ (g/day) $(n=37)$} \\
\hline & \multicolumn{4}{|c|}{$\%$} \\
\hline \multicolumn{5}{|l|}{ Sex } \\
\hline Male & \multicolumn{2}{|c|}{67.6} & \multicolumn{2}{|c|}{69.4} \\
\hline Female & \multicolumn{2}{|c|}{32.5} & \multicolumn{2}{|c|}{30.6} \\
\hline \multicolumn{5}{|l|}{$A g e^{a}$} \\
\hline Adult & \multicolumn{2}{|c|}{24.3} & \multicolumn{2}{|c|}{$47.2^{*}$} \\
\hline Elderly & \multicolumn{2}{|c|}{75.7} & \multicolumn{2}{|c|}{52.8} \\
\hline \multicolumn{5}{|l|}{ Weight-status $^{\mathrm{a}}$} \\
\hline Normal-weight & \multicolumn{2}{|c|}{48.6} & \multicolumn{2}{|c|}{50.0} \\
\hline Underweight & \multicolumn{2}{|c|}{21.6} & \multicolumn{2}{|c|}{33.3} \\
\hline Overweight & \multicolumn{2}{|c|}{29.7} & \multicolumn{2}{|c|}{16.7} \\
\hline \multirow{2}{*}{ Metabolic markers } & \multicolumn{2}{|c|}{ Low consumption $<128.4$ (g/day) $(\mathrm{n}=36)$} & \multicolumn{2}{|c|}{ High consumption $\geq 128.4$ (g/day) $(n=37)$} \\
\hline & $\mathrm{M} / \mathrm{M}_{\mathrm{d}}$ & $\mathrm{SD} / \mathrm{P}_{25}-\mathrm{P}_{75}$ & $\mathrm{M} / \mathrm{M}_{\mathrm{d}}$ & $\mathrm{SD} / \mathrm{P}_{25}-\mathrm{P}_{75}$ \\
\hline Serum calcium $(\mathrm{mmol} / \mathrm{L})^{\mathbf{b}}$ & 2.20 & 0.3 & 2.20 & 0.20 \\
\hline Calcium-phosphorus product ${ }^{\mathbf{b}}$ & 42.00 & 11.0 & 37.00 & 11.00 \\
\hline Serum phosphorus(mmol/L)c & 1.32 & $0.8-2.5$ & 1.58 & $0.60-2.40^{*}$ \\
\hline Potassium $(\mathrm{mmol} / \mathrm{L})^{\mathbf{b}}$ & 5.30 & 1.0 & 5.50 & 0.70 \\
\hline Glucose $(\mathrm{mmol} / \mathrm{L})^{c}$ & 8.15 & $6.6-9.8$ & 7.54 & $5.10-10.00$ \\
\hline Hemoglobin $(\mathrm{g} / \mathrm{L})^{\mathbf{b}}$ & 116.00 & 16.0 & 110.00 & 24.00 \\
\hline Hematocrit(ratio of 1.0$)^{\mathbf{b}}$ & 0.36 & 0.04 & 0.34 & 0.07 \\
\hline $\mathrm{Kt} / \mathrm{N}^{\mathrm{b}}$ & 1.50 & 0.40 & 1.60 & 0.30 \\
\hline Total cholesterol $(\mathrm{mmol} / \mathrm{L})^{\mathbf{b}}$ & 3.78 & 0.98 & 3.85 & 0.95 \\
\hline Triglycerides $(\mathrm{mmol} / \mathrm{L})^{c}$ & 1.69 & $1-2.45 .0$ & 2.20 & $1.20-2.60$ \\
\hline Creatinine $(\mathrm{mmol} / \mathrm{L})^{\mathbf{b}}$ & 760.00 & 212.0 & 804.00 & 238.00 \\
\hline Pre-dialysis urea $(\mathrm{mmol} / \mathrm{L})^{c}$ & 37.10 & $32.0-41.0$ & 47.10 & $34.00-40.00^{*}$ \\
\hline Post-dialysis urea $(\mathrm{mmol} / \mathrm{L})^{c}$ & 10.40 & $8.5-13.5$ & 11.40 & $9.20-17.50$ \\
\hline
\end{tabular}

Note: * : $p<0.05$. \%: a: Pearson's Chi-square test; ${ }^{\text {b. }}$ Student $t$ Test; ${ }^{c}$ : Mann Whitney U-test; Adults $\leq 59$ years and elderly $\geq 60$ years. HD: Hemodialysis; KtN: Dialysis efficiency; M: Mean; $M_{d}$ : Median; SD: Standard Deviation.

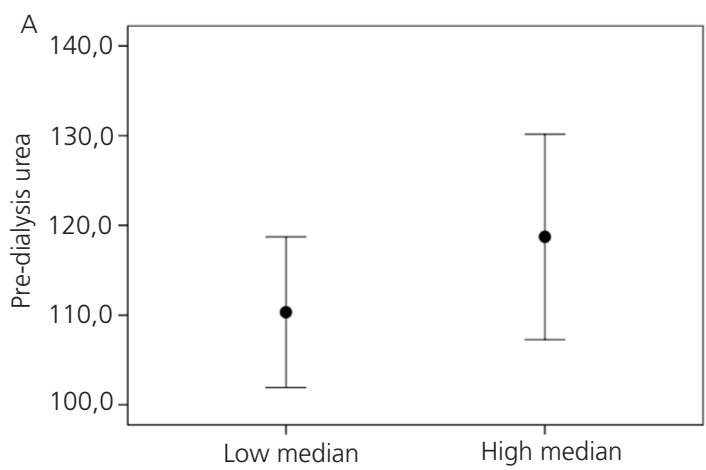

Consumption of processed meats, sausages and ready meals

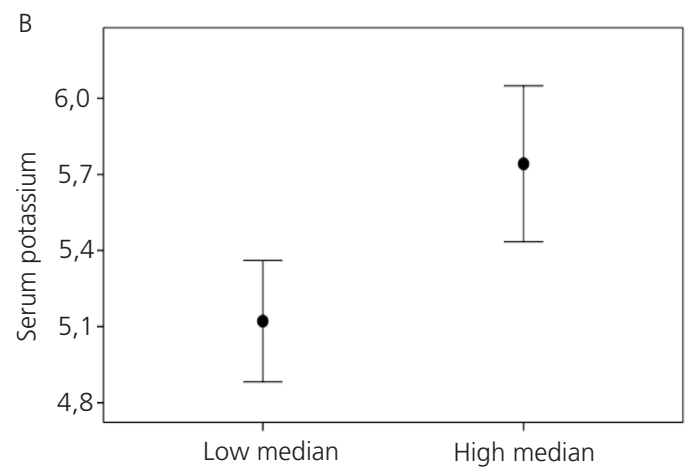

Consumption of spices and processed sauces

Figure 2. Metabolic markers according to the consumption of processed and ultra-processed foods

Note: Serum pre-dialysis urea (a) and potassium (b), according to specific processed and ultra-processed foods; p-values from Mann Whitney U-test; Values are presented as median and $95 \%$ Confidence Interval; Low $(n=36)$ and high $(n=37)$ consumers, according median values as cutoff (31 g for consumption of processed meats, sausages and ready meals; and 2,2g for consumption of spices and processed sauces, respectively). 


\section{DISCUSSION}

In this cross-sectional study, HD subjects who consumed more processed and ultra-processed foods had higher serum concentrations of pre-dialysis urea and phosphorus, important metabolic biomarkers in the CKD Stage-5. According to our literature search, apparently, this is the first study to evaluate the consumption of processed and ultra-processed food in HD individuals and its relation with metabolic markers. Processed and ultra-processed food, defined as industrialized products added sodium, sugar, fats and artificial substances, has been linked with poor diet quality due to increased consumption of these food additives [15]. Ultra-processed foods are attractive to the population because of their convenience (ready for consumption); pleasant taste; low cost, which makes them profitable and easy to find and transport. In addition, these products are advertised by the media with advertisements that influence the choices of the population [3].

In this study, the average consumption of these foods was $128.4 \mathrm{~g} /$ day. The consumption of calories, sodium and phosphorus was higher among individuals with high consumption of processed and ultra-processed. Thus, the phosphorus intake of these subjects was above the recommendation [22], as the processed foods are added this mineral with high bioavailability [22,23]. Since phosphorus retention is a risk factor for developing cardiovascular events and secondary hyperparathyroidism in CKD [23], this group of foods should be avoided, besides avoiding other food sources, using correctly phosphate binders and having a proper HD time.

Regarding lipid intake, the results were similar to those of Vaz et al. [24], Who assessed the fat intake of HD individuals. The consumption of total lipids was adequate [17] but cholesterol, saturated fat and trans fatty acids intake was above recommended [22], reflecting the low quality of dietary fat profile.

Another interesting result of this study was the contribution of processed and ultra-processed food in relation to total calories. In fact, individuals with higher consumption of processed and ultra-processed food presented higher caloric intake, since these foods had high energy density [15]. Another Brazilian research [25] had a lower mean intake of this food-group, compared to our study, but this survey had been not conducted with HD patients. In turn, the sodium intake in our population was higher than recommendation established for HD individuals [10]. Sodium intake from processed and ultra-processed food represented $12.5 \%$ of the total sodium consumed. As found in other studies the main source of this mineral is the addition salt [26].

However, individuals with higher consumption of processed and ultra-processed had higher intake of this mineral, showing the importance of the reduction sodium intake by controlling the consumption of these foods [26]. The current work also found a significant relationship between the consumption of processed and ultra-processed foods and metabolic markers. Individuals with higher consumption of these foods and the group of processed meats, sausages and ready preparations showed higher values of pre-dialysis serum urea. These foods are recognized as protein sources [25] and urea is directly related to the protein intake and endogenous degradation of proteins [12].

Thus, the higher the consumption of foods rich in protein, the higher the serum urea. Another study that examined the phosphorus and protein content of the processed foods most consumed by HD individuals noted that the amount of protein consumed in these foods was greater than in the fresh food, due to the presence of food additives rich in nitrogen, such as nitrites and nitrates [4]. Our results suggest that the consumption of these foods can interfere with uremic control of HD 
individuals, which is crucial for life quality and retarding morbidity and mortality in these patients. In turn, the serum potassium values were higher in individuals with a higher intake of ready sauces and seasoning salt-based. The sauces and tomato extracts should be avoided for containing large amounts of this nutrient [27], explaining the cause of elevated serum potassium.

Although there has been no difference among individuals with hyperkalemia and the consumption of processed and ultra-processed foods, hyperkalemia is a major cause of cardiac complications, because it increases the excitability of the nervous and cardiac systems $[28,29]$. However, our study is the first to report that these associations need more studies to establish factors and mechanisms involved.

Our study had certain limitations. First, since the nature of this study is cross-sectional, we cannot prove that the reported associations are causal because residual confounding may have affected the observed associations. Second, dietary exposures can be misclassified despite the good correlation between food frequency questionnaires and usual diet, but the dietary questionnaire has been successfully applied to investigate the relationship between food-groups consumption and metabolic markers $[20,30]$. Third, although the sample size is adequate from the standpoint of initial association discovery, further replication in independent and larger samples will be convenient for a future translational application at population level.

\section{CONCLUSION}

In conclusion, this cross-sectional study found an important consumption of processed and ultra-processed foods among HD individuals, being related to phosphorus and serum urea, which are important metabolic markers in this population. In addition, the content of trans fatty acids and salt of these foods may also be involved in this relationship, so the consumption of processed and ultra-processed foods should be discouraged.

\section{A CKNOWLEDGMENTS}

We wish to thank all participants in this study, and São João Batista Hospital's staff for excellent technical assistance. We also thank to the Coordination for Higher Education Staff Development (Capes), Foundation (Ministry of Education, Brazil), National Council for Scientific and Technological Development (CNPq) and Research Support Foundation of the States of Minas Gerais (Fapemig) .

\section{CONTRIBUTORS}

AL Wendling, is main author of the article, responsible for data collection, data analysis and article elaboration. KP Balbino and APS Epifânio, was responsible for writing and reviewing the article. PVM Ribeiro was responsible by analyzing the data, preparing and writing the article. LD Marota was responsible by design, field work, and data collection. HHM Hermsdorff is the advisor of the work, responsible for data analysis and elaboration of the article.

\section{REFERENCES}

1. Hanafusa N, Lodebo BT, Kopple JD. Current uses of dietary therapy for patients with far-advanced CKD. Clin J Am Soc Nephrol. 2017;12(7):1190-5. http://dx.doi.org/10.2215/CJN.09340916 
2. Rysz J, Franczyk B, Ciałkowska-Rysz A, Gluba-Brzózka A. The effect of diet on the survival of patients with chronic kidney disease. Nutrients. 2017;9(5):495.

3. Hruby A, Hu FB. The epidemiology of obesity: a big picture. Pharmacoeconomics. 2015;33(7):673-89. http:// dx.doi.org/10.1007/s40273-014-0243-x

4. Watanabe MT, Araujo RM, Vogt BP, Barretti P, Caramori JCT. Most consumed processed foods by patients on hemodialysis: alert for phosphate-containing additives and the phosphate-to-protein ratio. Clin Nutr Espen. 2016;14:37-41. http://dx.doi.org/10.1016/j.clnesp.2016.05.001

5. Moradi H, Vaziri ND. Molecular mechanisms of disorders of lipid metabolism in chronic kidney disease. Front Biosci. 2017;23(1):146-61. http://dx.doi.org/ 10.2741/4585

6. World Health Organization. Physical status: the use of and interpretation of anthropometry. Report of a WHO Expert Committee. Geneva: The Organization; 1995.

7. Lipschitz DA. Screening for nutritional status in the elderly. Prim Care. 1994;21(1):55-67.

8. World Health Organization. Definition and diagnosis of diabetes mellitus and intermediate hyperglycemia. Report of a WHO/IDF Consultation. Geneva: The Organization; 2006.

9. Ministério da Saúde. Diretrizes clínicas para o cuidado ao paciente com doença renal crônica: DRC no Sistema Único de Saúde. Brasília: Ministério da Saúde; 2014.

10. Biruete A, Jeong JH, Barnes $\mathrm{JL}$, Wilund KR. Modified nutritional recommendations to improve dietary patterns and outcomes in hemodialysis patients. J Ren Nutr. 2017;27(1):62-70. http://dx.doi.org/10.1053/j. jrn.2016.06.001

11. Faludi AA, Izar MCO, Saraiva JFK, Chacra APM, Bianco HT, Afiune Neto A, et al. Atualização da Diretriz Brasileira de Dislipidemias e Prevenção da Aterosclerose. Arq Bras Cardiol. 2017;109(1).

12. Riella MC. Nutrição e o rim. 2 ed. Rio de Janeiro: Guanabara Koogan; 2013.

13. Fermi MRV. Diálise para enfermagem: guia prático. 2 ed. Rio de Janeiro: Guanabara Koogan; 2010.

14. Mason B, Ross L, Gill E, Healy H, Juffs P, Kark A. Development and validation of a dietary screening tool for high sodium consumption in Australian renal patients. J Ren Nutr. 2014;24(2):123-34. http://dx.doi.org/ 10.1053/j.jrn.2013.10.004

15. Ministério da Saúde. Secretaria de Atenção à Saúde. Guia alimentar para a população brasileira. 2 ed. Brasília: Ministério da Saúde; 2014.

16. Louzada MLC, Martins APB, Canella DS, Baraldi LG, Levy RB, Claro RM, et al. Ultra-processed foods and the nutritional dietary profile in Brazil. Rev Saúde Pública. 2015;49. http://dx.doi.org/10.1590/S0034-89 10.2015049006132

17. Instituto Brasileiro de Geografia e Estatística. Pesquisa de orçamentos familiares 2008-2009: análise do consumo alimentar pessoal no Brasil. Rio de Janeiro: IBGE; 2011.

18. Ministério da Saúde. Secretária de Atenção à Saúde. Guia alimentar para a população brasileira: promovendo a alimentação saudável. Brasília: Ministério da Saúde; 2008.

19. Willett W, Stampfer MJ. Total energy intake: implications for epidemiologic analyses. Am J Epidemiol. 1986;124(1):17-27.

20. Epifânio APS, Balbino PK, Jorge MP, Ribeiro SMR, Moreira AVBM, Oliveira JM, et al. Metabolic, inflammatory and oxidative stress markers in the nitric oxide variation of hemodialysis subjects. Nutr Hosp. 2018;35(1):176-84. http://dx.doi.org/10.20960/nh.1319

21. Martínez González MA, Sánchez Villegas A, Toledo Atucha E, Faulín Fajardo FJ. Bioestadística amigable. 3 ed. Barcelona: Elsevier; 2013.

22. Bogacka A, Sobczak-Czynsz A, Kucharska E, Madaj M, Stucka K. Analysis of nutrition and nutritional status of haemodialysis patients. Rocz Panstw Zakl Hig. 2018;69(2):165-74.

23. Ketteler M, Block GA, Evenepoel P, Fukagawa M, Herzog CA, McCann L, et al. Diagnosis, evaluation, prevention, and treatment of chronic kidney disease-mineral and bone disorder: synopsis of the kidney disease: improving global outcomes 2017 clinical practice guideline update. Ann Intern Med. 2018;168(6):422.

24. Vaz IMF, Freitas ATVS, Peixoto MRG, Ferraz SF, Campos MIVAM. Food intake in patients on hemodialysis. Rev Nutr. 2014;27(6):665-75. http://dx.doi.org/10.1590/1415-52732014000600002 
25. Louzada MLC, Martins APB, Canella DS, Baraldi LG, Levy RB, Claro RM, et al. Impact of ultra-processed foods on micronutrient content in the Brazilian diet. Rev Saúde Pública. 2015;49:1-8.

26. Wu P-Y, Yang S-H, Wong T-C, Chen T-W, Chen H-H, Chen T-H, et al. Association of processed meat intake with hypertension risk in hemodialysis patients: a cross-sectional study. Plos One. 2015;10(10):e0141917. http://dx.doi.org/10.1371/journal.pone.0141917

27. Copetti C, Oliveira VR, Kirinus P. Avaliação da redução de potássio em hortaliças submetidas a diferentes métodos de cocção para possível utilização na dietoterapia renal. Rev Nutr. 2010;23(5):831-8.

28. Hannedouche T, Fouque $D$, Joly D. Complications métaboliques en insuffisance rénale chronique: hyperphosphatémie, hyperkaliémie et anémie. Néphrol Thér. 2018;14(6):6S17-25. http://dx.doi.org/10.1016/ s1769-7255(18)30647-3

29. Palmer BF, Clegg DJ. Treatment of abnormalities of potassium homeostasis in CKD. Adv Chronic Kidney Dis. 2017;24(5):319-24. http://dx.doi.org/10.1053/j.ackd.2017.06.001

30. Cocate PG, Natali AJ, Oliveira A, Alfenas RCG, Peluzio MCG, Longo GZ, et al. Red but not white meat consumption is associated with metabolic syndrome, insulin resistance and lipid peroxidation in Brazilian middle-aged men. Eur J Prev Cardiol. 2015;22(2):223-30. http://dx.doi.org/10.1177/2047487313507684 